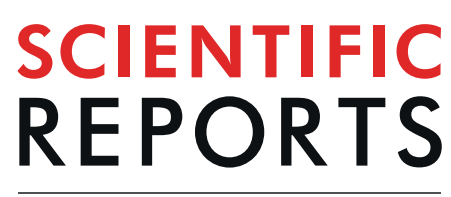

natureresearch

Check for updates

\title{
Elemental characterization of oral cavity squamous cell carcinoma and its relationship with smoking, prognosis and survival
}

\author{
Anderson Barros Archanjo $\circledast^{1,9 凶}$, Arícia Leone Evangelista Monteiro de Assis ${ }^{1,9}$, \\ Mayara Mota de Oliveira ${ }^{1}$, Suzanny Oliveira Mendes ${ }^{1}$, Aline Ribeiro Borçoi ${ }^{1}$, \\ Lucas de Lima Maia ${ }^{1}$, Rafael Pereira de Souza ${ }^{2}$, Rafael de Cicco ${ }^{2}$, Kelly Cristina Saito ${ }^{3}$, \\ Edna Teruko Kimura ${ }^{3}$, Marcos Brasilino de Carvalho ${ }^{4}$, Fabio Daumas Nunes ${ }^{5}$, \\ Eloiza H. Tajara ${ }^{6}$, Marcelo dos Santos ${ }^{7}$, Breno Valentim Nogueira ${ }^{1}$, Leonardo Oliveira Trivilin ${ }^{8}$, \\ Christiano Jorge Gomes Pinheiro ${ }^{8} \&$ Adriana Madeira Álvares-da-Silva ${ }^{1}$
}

Oral cancer squamous cell carcinoma (OCSCC) mainly affects individuals aged between 50 and 70 years who consume tobacco and alcohol. Tobacco smoke contains hundreds of known toxic and carcinogenic molecules, and a few studies have sought to verify the relationship of such trace elements as risk or prognostic factors for head and neck cancer. We obtained 78 samples of tumor tissues from patients with OCSCC, and performed a qualitative elemental characterization using the microX-Ray Fluorescence technique based on synchrotron radiation. We found the presence of magnesium, phosphorus, sulfur, chlorine, potassium, calcium, chromium, manganese, iron, zinc, cobalt, nickel, copper, arsenic and bromine in OCSCC samples. Magnesium, chlorine, chromium, manganese, nickel, arsenic and bromine are associated with smoking. We observed a significant association between relapse and chlorine and chromium. The presence of chlorine in the samples was an independent protective factor against relapse $(\mathrm{OR}=0.105, \mathrm{Cl}=0.01-0.63)$ and for best disease-free survival $(\mathrm{HR}=0.194, \mathrm{Cl}=0.04-0.87)$. Reporting for the first time in oral cancer, these results suggest a key relationship between smoking and the presence of certain elements. In addition, chlorine proved to be important in the context of patient prognosis and survival.

Squamous cell carcinoma (SCC) accounts for more than $90 \%$ of oral cancer cases ${ }^{1,2}$ and mainly affects individuals aged between 50 and 70 years who consume tobacco and alcohol. It may also be associated with human papillomavirus infection, genetic susceptibility and passive smoking exposure ${ }^{1-5}$. Tobacco smoke itself, which contains hundreds of known toxic and carcinogenic molecules ${ }^{6,7}$, can induce DNA damage ${ }^{8}$. Among these substances are several inorganic compounds, such as arsenic, calcium, chlorine, cobalt, copper, chromium, iron, magnesium, manganese, nickel, potassium, zinc and others ${ }^{9,10}$.

The analysis of trace elements is quite uncommon in the head and neck cancer field. Over the past two decades, a few studies have sought to verify the identity of these and other trace elements as risk or prognostic factors for head and neck cancer. Some authors verified the differences in the profile of trace elements in the blood (plasma/serum) of patients with or without head and neck cancer ${ }^{11-19}$. Differences were also found in the analyses performed on the hair and nails of patients with head and neck cancer ${ }^{15,17,20,21}$. However, in studies carried out

${ }^{1}$ Postgraduate Program in Biotechnology/RENORBIO, Federal University of Espirito Santo, Av. Marechal Campos, 1468, Vitoria, 29.040-090, ES, Brazil. ${ }^{2}$ Cancer Institute Arnaldo Vieira de Carvalho, São Paulo, Brazil. ${ }^{3}$ Institute of Biomedical Science, University of São Paulo, São Paulo, Brazil. 'Molecular Biology Laboratory, Heliópolis Hospital, São Paulo, Brazil. ${ }^{5}$ School of Dentistry, University of São Paulo, São Paulo, Brazil. ${ }^{6}$ Medical School of São José do Rio Preto, São José do Rio Preto, Brazil. ${ }^{7}$ Multicampi School of Medical Sciences of Rio Grande do Norte, Federal University of Rio Grande do Norte, Caicó, Brazil. ${ }^{8}$ Center for Agricultural Sciences and Engineering, Federal University of Espirito Santo, Alegre, Brazil. ${ }^{9}$ These authors contributed equally: Anderson Barros Archanjo and Arícia Leone Evangelista Monteiro de Assis. ${ }^{凶} \mathrm{e}$-mail: andersonarchanjo@gmail.com 
on saliva, there were divergent results. Dziewuska et al. ${ }^{22}$ found no evidence of mineral markers in oral cancer, whereas Shetty et al. ${ }^{23}$ reported an increase in copper and a decrease in zinc in the saliva of patients with oral cancer.

A few studies have been conducted on tumor tissues. In thyroid cancer, for example, Zaichick et al. ${ }^{24}$ found higher levels of silver, cobalt, mercury, iodine and rubidium in malignant nodules and Baltaci et al. ${ }^{25}$ found changes in the levels of zinc and selenium in thyroid tissues. Regarding breast cancer, Majewska et al. ${ }^{26}$ reported differences in the concentration of some elements between benign and malignant tumors. Geraki et al. ${ }^{27}$ found that an increase in potassium and zinc is bigger than that of iron and copper. Silva et al. ${ }^{28}$ reported that trace elements may be potential markers in breast tumors and the authors emphasized that patients with elemental copper presence had lower survival.

In view of the above, most of the studies carried out used other types of samples, such as blood, hair, nails and saliva, and the studies that used tumor tissue were from anatomical sites different from ours. Thus, there is no consensus on what elements could be found in head and neck cancer. Given the knowledge gap in the link between tobacco elements and oral cancer prognosis, this study aimed to qualitative characterize the presence of elements in oral cavity cancers samples according to smoking status and verify the possible association of these elements with prognosis and survival.

\section{Results}

Relationship between smoking status and elemental characterization. The elements found in oral cavity SCC (OCSCC) samples were magnesium, phosphorus, sulfur, chlorine, potassium, calcium, chromium, manganese, iron, zinc, cobalt, nickel, copper, arsenic and bromine (Table 1).

Stratification of the elements by smoking status revealed that the presence of magnesium $(\mathrm{p}<0.0001)$, chromium $(p=0.006)$ and manganese $(p=0.002)$ was associated with smoking. The highest percentages of these elements were found in individuals who had stopped smoking, whereas magnesium and manganese were absent in those who had never smoked. Arsenic and bromine $(\mathrm{p}=0.011 \mathrm{for}$ both) were present in the highest amounts in individuals who had a smoking habit, whether in the past or present (Table 1).

Chromium was associated with a history of tobacco use $(\mathrm{p}=0.003)$, whereas it was absent in the cancer tissue samples of individuals who had never used tobacco. Arsenic and bromine ( $p=0.026$ for both) were present in the highest amounts in individuals with a history of tobacco consumption (Table 1).

Regarding current tobacco consumption, elemental stratification showed an association between chlorine and current tobacco consumption $(\mathrm{p}=0.043$ ). Only $25 \%$ of individuals who currently consumed tobacco had detectable chlorine in the tumor samples. Nickel, on the other hand, was present in less than $3 \%$ of the tumor samples of patients who did not currently consume tobacco $(\mathrm{p}=0.005)$ (Table 1$)$.

Role of elements as prognostic factors in oral cancer. We identified associations between the presence of some elements and the prognosis of patients with oral cancer. There was a significant association between manganese and recurrence-free survival (Wilcoxon $\mathrm{p}=0.008$ ). During the first 12 months after surgery, $40.0 \%$ of patients with manganese present in oral cavity cancer samples suffered from recurrence while only $16.8 \%$ of patients without manganese detection had relapsed (see Fig. 1).

We observed a significant association between relapse and chlorine and chromium $(p=0.037$ and $p=0.034$, respectively; Table 2). In a multivariate analysis, the presence of chlorine in the samples was an independent protective factor against relapse, with a reduced risk (odds ratio $[\mathrm{OR}]=0.105$, confidence interval $[\mathrm{CI}]=0.01-0.63$; Table 3). Regarding chlorine, we also found that at 18 months after surgery, $30 \%$ of patients without chlorine in their samples had relapsed, whereas in the same period only $12.8 \%$ of the patients with chlorine suffered from recurrence (see Fig. 2). Multivariate analysis revealed that the presence of chlorine was an independent protective factor for better disease-free survival, conferring a reduced risk (hazard ratio $[\mathrm{HR}]=0.194, \mathrm{CI}=0.04-0.87$; Table 3).

\section{Discussion}

Determining the elemental profile of head and neck cancer tumor tissue is a very novel and highly relevant issue, as it may reveal not only the relationship between these elements and smoking, but also the influence of such elements on the prognosis and survival of cancer patients. To the best of our knowledge, this is the first study to perform a qualitative elemental characterization (presence or absence) of tumor tissue samples from patients with OCSCC using the micro-XRF technique based on synchrotron radiation and correlate these elements with smoking habits, prognosis and survival. In our study, we verified the presence of the elements magnesium, phosphorus, sulfur, chlorine, potassium, calcium, chromium, manganese, iron, zinc, cobalt, nickel, copper, arsenic and bromine, of which some were associated with smoking, prognosis, and survival of our patients. A similar approach was performed in patients with thyroid $\operatorname{cancer}^{24,25}$ and breast cancer ${ }^{26-28}$. Other studies in head and neck cancer patients have analyzed the levels of some trace elements in the blood ${ }^{11-19}$, hair or nails ${ }^{15,17,20,21}$ and in saliva $^{22,23}$. It is worth mentioning that we found few studies that analyzed trace elements in the tumor tissue, these being in thyroid or breast cancer.

We found that magnesium, chlorine, chromium, manganese, nickel, arsenic and bromine were associated with smoking habits, be it a former or current habit. This link is important because cigarette smoke contains innumerable chemical substances and compounds, some of which are the elements found in tumor tissue samples in this study. Tobacco smoke is a complex and reactive mixture containing more than 5,000 chemicals $^{29}$, including elements, such as magnesium, potassium, calcium, chromium, manganese, iron, cobalt, nickel, copper and zinc, semimetal arsenic, non-metal chlorine, and others ${ }^{7,9,10}$. In addition, studies show that even smokeless tobacco 


\begin{tabular}{|c|c|c|c|c|c|c|c|c|c|c|c|}
\hline \multirow[b]{2}{*}{ Element } & \multirow[b]{2}{*}{$\begin{array}{l}\text { All patients } \\
(\mathrm{n}=78)\end{array}$} & \multicolumn{4}{|l|}{ Smoking } & \multicolumn{3}{|c|}{ History of tobacco consumption } & \multicolumn{3}{|c|}{ Current tobacco consumption } \\
\hline & & $\begin{array}{l}\text { Never } \\
(\mathrm{n}=14)\end{array}$ & $\begin{array}{l}\text { Former } \\
(\mathbf{n}=23)\end{array}$ & $\begin{array}{l}\text { Current } \\
(\mathrm{n}=41)\end{array}$ & $P-$ & $\mathrm{No}^{1}(\mathrm{n}=14)$ & $\operatorname{Yes}^{2}(n=64)$ & $P-$ & $\mathrm{No}^{3}(\mathrm{n}=37)$ & $\operatorname{Yes}^{4}(n=41)$ & $P-$ \\
\hline \multicolumn{12}{|c|}{ Magnesium } \\
\hline Absent & $69(88.5)$ & $14(100.0)$ & $15(65.2)$ & $40(97.6)$ & 0.000 & $12(85.7)$ & $57(89.1)$ & 0.722 & $31(83.8)$ & $38(92.7)$ & 0.191 \\
\hline Present & $9(11.5)$ & $0(0.0)$ & $8(34.8)$ & $1(2.4)$ & & $2(14.3)$ & $7(10.9)$ & & $6(16.2)$ & $3(7.3)$ & \\
\hline \multicolumn{12}{|c|}{ Phosphorus } \\
\hline Absent & $5(6.5)$ & $1(7.1)$ & $1(4.4)$ & $3(7.3)$ & 0.891 & $2(14.3)$ & $3(4.7)$ & 0.184 & $2(5.4)$ & $3(7.3)$ & 0.549 \\
\hline Present & $73(93.6)$ & $1392.9)$ & $22(95.6)$ & $38(92.7)$ & & $12(85.7)$ & $61(95.3)$ & & $35(94.6)$ & $38(92.7)$ & \\
\hline \multicolumn{12}{|l|}{ Sulfur } \\
\hline Absent & $1(1.3)$ & $0(0.0)$ & $1(4.4)$ & $0(0.0)$ & 0.298 & $0(0.0)$ & $1(1.5)$ & 0.638 & $1(2.7)$ & $0(0.0)$ & 0.474 \\
\hline Present & 77 (98.7) & $14(100.0)$ & $22(95.6)$ & $41(100.0)$ & & $14(100.0)$ & \begin{tabular}{|l|}
$63(98.5)$ \\
\end{tabular} & & $36(97.3)$ & $41(100.0)$ & \\
\hline \multicolumn{12}{|c|}{ Chlorine } \\
\hline Absent & $50(64.1)$ & $12(85.7)$ & $14(60.9)$ & $24(58.5)$ & 0.174 & 11 (78.6) & $39(60.9)$ & 0.213 & $28(75.7)$ & 22 (53.6) & 0.043 \\
\hline Present & $28(35.9)$ & $2(14.3)$ & $9(39.1)$ & $17(41.5)$ & & $3(21.4)$ & $28(39.1)$ & & $9(24.3)$ & $19(46.4)$ & \\
\hline \multicolumn{12}{|c|}{ Potassium } \\
\hline Absent & $14(17.9)$ & $4(28.6)$ & $3(13.1)$ & $7(17.1)$ & 0.480 & $5(35.7)$ & $9(14.1)$ & 0.056 & $8(21.6)$ & $6(14.6)$ & 0.422 \\
\hline Present & $64(82.1)$ & $10(71.4)$ & $20(86.9)$ & $34(82.9)$ & & $9(64.3)$ & $55(85.90$ & & $29(78.4)$ & 35 (85.4) & \\
\hline \multicolumn{12}{|l|}{ Calcium } \\
\hline Absent & $1(1.3)$ & $1(7.1)$ & $0(0.0)$ & $0(0.0)$ & 0.099 & $1(7.1)$ & $0(0.0)$ & 0.179 & $1(2.7)$ & $0(0.0)$ & 0.474 \\
\hline Present & 77 (98.7) & $13(92.90$ & $23(100.0)$ & $41(100.0)$ & & $13(92.8)$ & $64(100.00$ & & $36(97.3)$ & $41(100.0)$ & \\
\hline \multicolumn{12}{|c|}{ Chromium } \\
\hline Absent & $45(57.7)$ & $13(92.9)$ & $9(39.1)$ & $23(56.1)$ & 0.006 & $13(92.9)$ & $32(50.0)$ & 0.003 & $24(64.9)$ & $21(51.2)$ & 0.223 \\
\hline Present & $33(42.3)$ & $1(7.1)$ & $14(60.9)$ & $18(43.9)$ & & $1(7.10)$ & $32(50.0)$ & & $13(35.1)$ & 20 (48.7) & \\
\hline \multicolumn{12}{|c|}{ Manganese } \\
\hline Absent & $52(66.7)$ & $14(100.0)$ & $10(43.5)$ & $28(68.3)$ & 0.002 & $12(85.7)$ & $40(66.7)$ & 0.095 & $26(70.3)$ & $26(63.4)$ & 0.521 \\
\hline Present & $26(33.3)$ & $0(0.0)$ & $13(56.5)$ & $13(31.7)$ & & $2(14.3)$ & $26(33.3)$ & & $11(29.7)$ & $15(36.6)$ & \\
\hline \multicolumn{12}{|l|}{ Iron } \\
\hline Absent & $0(0.0)$ & $0(0.0)$ & $0(0.0)$ & $0(0.0)$ & 1.000 & $0(0.0)$ & $0(0.0)$ & 1.000 & $0(0.0)$ & $0(0.0)$ & 1.000 \\
\hline Present & $78(100.0)$ & $14(100.0)$ & $23(100.0)$ & $41(100.0)$ & & $14(100.0)$ & $64(100.0)$ & & $37(100.0)$ & $41(100.0)$ & \\
\hline \multicolumn{12}{|l|}{ Cobalt } \\
\hline Absent & $69(88.5)$ & $12(85.7)$ & $18(78.3)$ & $39(95.1)$ & 0.121 & $10(71.4)$ & $59(92.2)$ & 0.050 & $32(86.5)$ & $37(88.5)$ & 0.433 \\
\hline Present & $9(11.5)$ & $2(14.3)$ & $5(21.7)$ & $2(4.9)$ & & $4(28.6)$ & $5(7.8)$ & & $5(13.5)$ & $4(11.5)$ & \\
\hline \multicolumn{12}{|l|}{ Nickel } \\
\hline Absent & $67(85.9)$ & $14(100.0)$ & $20(86.9)$ & $33(80.5)$ & 0.191 & $13(92.8)$ & $54(84.4)$ & 0.409 & $36(97.3)$ & $31(75.6)$ & 0.005 \\
\hline Present & $11(14.1)$ & $0(0.0)$ & $3(13.1)$ & $8(19.5)$ & & $1(7.2)$ & 10 (15.6) & & $1(2.7)$ & $10(24.4)$ & \\
\hline \multicolumn{12}{|l|}{ Copper } \\
\hline Absent & $4(5.1)$ & $1(7.1)$ & $1(4.3)$ & $2(4.9)$ & 0.927 & $1(7.1)$ & $3(4.7)$ & 0.706 & $2(5.4)$ & $2(4.9)$ & 0.652 \\
\hline Present & $74(94.9)$ & $13(92.9)$ & $22(95.7)$ & 39 (95.1) & & $13(92.9)$ & $61(95.3)$ & & $35(94.6)$ & $39(95.1)$ & \\
\hline \multicolumn{12}{|l|}{ Zinc } \\
\hline Absent & $0(0.0)$ & $0(0.0)$ & $0(0.0)$ & $0(0.0)$ & 1.000 & $0(0.0)$ & $0(0.0)$ & 1.000 & $0(0.0)$ & $0(0.0)$ & 1.000 \\
\hline Present & $78(100.0)$ & $14(100.0)$ & $23(100.0)$ & $41(100.0)$ & & $14(100.0)$ & $64(100.0)$ & & $37(100.0)$ & $41(100.0)$ & \\
\hline \multicolumn{12}{|l|}{ Arsenic } \\
\hline Absent & $25(32.1)$ & $9(64.3)$ & $4(17.4)$ & $12(29.3)$ & 0.011 & $8(57.1)$ & $17(26.5)$ & 0.026 & $14(37.8)$ & $11(26.9)$ & 0.298 \\
\hline Present & $53(67.9)$ & $5(35.7)$ & $19(82.6)$ & 29 (70.7) & & $6(42.9)$ & 47 (73.5) & & $23(62.2)$ & $30(73.1)$ & \\
\hline \multicolumn{12}{|l|}{ Bromine } \\
\hline Absent & $25(32.1)$ & $9(64.3)$ & $4(17.4)$ & $12(29.3)$ & 0.011 & $8(57.1)$ & 17 (26.5) & 0.026 & $14(37.8)$ & $11(26.9)$ & 0.298 \\
\hline Present & $53(67.9)$ & $5(35.7)$ & $19(82.6)$ & 29 (70.7) & & $6(42.9)$ & 47 (73.5) & & $23(62.2)$ & $30(73.1)$ & \\
\hline
\end{tabular}

Table 1. Elemental characterization of oral cavity squamous cell carcinoma samples according to patients' smoking habits. ${ }^{1}$ No, Never; ${ }^{2}$ Yes, Former/Current; ${ }^{3}$ No, Never/Former; ${ }^{4}$ Yes: Current; Data represented as absolute counts (\%).

products contribute to the accumulation of nickel and arsenic and that can be synergistic to the risk factors associated with oral cancer ${ }^{30,31}$.

In our study, we verified the presence of other elements, such as zinc and copper, which, despite not having a significant association with smoking, were present in the tumor samples, and thus deserve to be highlighted. The literature shows us that such elements, even in tissue, nails, hair or blood, can be associated with smoking and pose a risk for head and neck cancer. Studies have also shown that low levels of zinc in the nails pose a high risk 


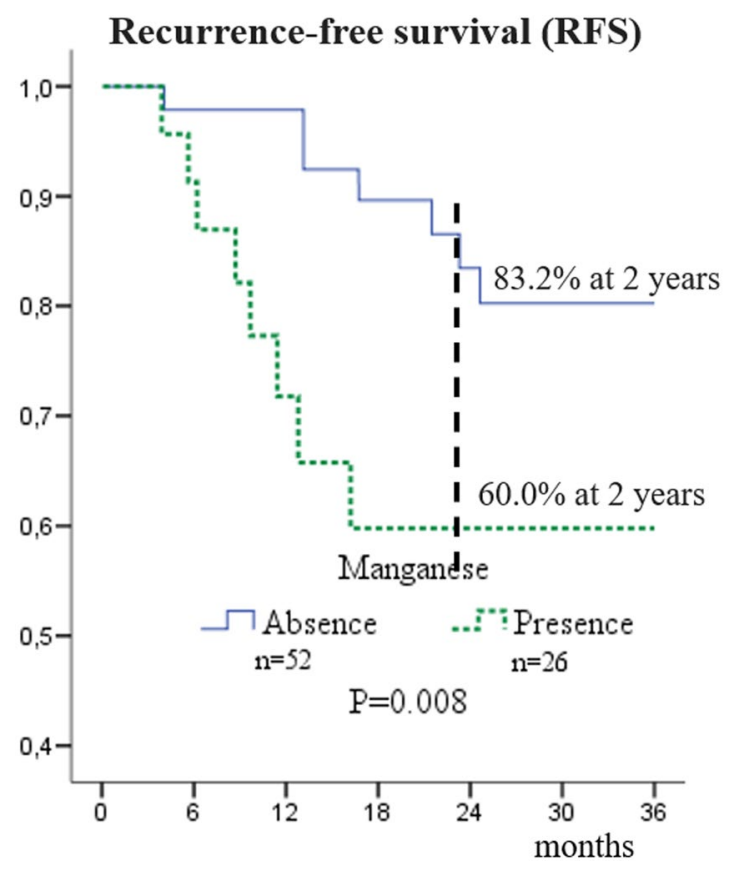

Figure 1. Recurrence-free survival (RFS) curves of patients with squamous cell carcinoma of the oral cavity according to status of manganese.

for oral cancer, even when adjusted for smoking and alcohol use ${ }^{19,32}$. In their study, Wozniak et al. ${ }^{21}$ analyzed the hair of patients with laryngeal cancers and found lower levels of zinc in smokers than in nonsmokers. This may be due to the cadmium contained in cigarette smoke having an antagonistic effect on zinc, leading to zinc reduction $^{33}$. In blood, for example, Bandeira et al. ${ }^{18}$ reported lower copper concentrations in patients with oral cancer, although these were nonsmokers. However, Chen et al. ${ }^{19}$ demonstrated the relationship between copper and zinc in the context of smoking; they observed higher concentrations of copper in smokers, which conferred a greater risk for oral cancer. Thus, it is worth mentioning that zinc and copper are important elements in head and neck cancer, and that their role in tumor tissues should be studied further.

In addition to the relationships already demonstrated with smoking, chromium and manganese were associated with recurrence and recurrence-free survival, respectively. Khlifi et al. ${ }^{34}$ reported higher concentrations of chromium and nickel in the blood of patients with head and neck cancer, with concentrations being the highest in smokers. Yuan et al. ${ }^{35}$ found an association between serum levels of nickel and chromium and oral cancer. The same authors reported that the concentrations of chromium and nickel were higher in smokers. In addition to tobacco, other sources of exposure can lead to contamination with chromium. In this context, Tsai et al. ${ }^{36}$ found higher levels of chromium in patients with oral cancer that was associated with possible soil contamination in Taiwan. Some studies report that chromium in low concentrations can be used for medicinal purposes, and that it is involved in the metabolism of carbohydrates, lipids and proteins. Nevertheless, in sufficiently high concentrations, chromium becomes toxic and carcinogenic ${ }^{37}$. However, none of the authors cited analyzed the relationship of chromium with prognostic and survival factors. Thus, further studies should be carried out to verify the real relationship of chromium with these factors, with this study being an initial source of observation. Nevertheless, studies point to consistent evidence that patients who maintain smoking habits after being diagnosed with head and neck cancer have the lowest survival rates and the highest rates of recurrence ${ }^{38}$. Moreover, tobacco and alcohol consumption influence overall survival, highlighting the importance of discontinuing the use of these substances $^{39}$. In addition, smoking, alcohol consumption, and an inadequate diet can disrupt the levels of elements necessary for the body to function properly and increase the concentrations of toxic and health-threatening metals ${ }^{40}$.

The element chlorine was identified as a protective factor for recurrence and for better recurrence-free survival. Chloride ions $\left(\mathrm{CI}^{-}\right)$have great physiological relevance with an important role in cellular homeostasis under physiological and pathological conditions. Variations in $\mathrm{Cl}^{-}$flow are associated with cell volume regulation, secretory processes and cellular $\mathrm{pH}$ maintenance, all of which are essential to maintain enzymatic activity and cell cycle ${ }^{41-44}$. Recent studies have shown that $\mathrm{Cl}^{-}$act as secondary messengers; their concentration within the cell is dynamic, modulating the activity of transferrin, glucose-6-phosphatase and hemoglobin, among others ${ }^{45}$. The role of $\mathrm{Cl}^{-}$in cellular physiology is well defined; nevertheless, their relationship with cancer pathogenesis remains unclear. Following the discovery of binding of multidrug resistance protein (MDR/P-glycoprotein) to the activity of volume-activated chloride channels in the cancer cells of patients undergoing chemotherapy, chlorine channels gained prominence ${ }^{46}$. Some studies have reported a relationship between chlorine channel expression and patient prognosis and survival. Ruiz et al. ${ }^{47}$ found that expression of ANO1 $\left(\mathrm{Ca}^{2+}\right.$-activated chloride channel) causes cell migration, leading to a poor prognosis of head and neck squamous cell carcinoma. Duvvuri et al ${ }^{48}$ reported that expression of TMEM16A (also known as TAOS2, DOG1, and ANO1) induced proliferation and activation of 


\begin{tabular}{|c|c|c|c|c|c|c|}
\hline \multirow[b]{2}{*}{ Element } & \multicolumn{3}{|l|}{ Recurrence } & \multicolumn{3}{|l|}{ Death } \\
\hline & No $(n=63)$ & Yes $(n=15)$ & P- & No $(n=49)$ & Yes $(n=29)$ & P- \\
\hline \multicolumn{7}{|c|}{\begin{tabular}{|l} 
Magnesium \\
\end{tabular}} \\
\hline Absent & $54(85.7)$ & $15(100.0)$ & 0.129 & 44 (89.8) & $25(86.2)$ & 0.446 \\
\hline Present & $9(14.3)$ & $0(0.0)$ & & $5(10.2)$ & $4(13.8)$ & \\
\hline \multicolumn{7}{|c|}{ Phosphorus } \\
\hline Absent & $4(6.3)$ & $1(6.7)$ & 0.620 & $5(10.2)$ & $0(0.0)$ & 0.090 \\
\hline Present & $59(93.7)$ & 14 (93.3) & & \begin{tabular}{|l|}
$44(89.8)$ \\
\end{tabular} & $29(100.0)$ & \\
\hline \multicolumn{7}{|l|}{ Sulfur } \\
\hline Absent & $1(1.6)$ & $0(0.0)$ & 0.807 & $1(2.0)$ & $0(0.0)$ & 0.628 \\
\hline Present & $62(98.4)$ & $15(100.0)$ & & 48 (98.0) & $29(100.0)$ & \\
\hline \multicolumn{7}{|c|}{ Chlorine } \\
\hline Absent & $37(58.7)$ & $13(86.7)$ & 0.037 & 31 (63.3) & 19 (65.5) & 0.841 \\
\hline Present & $26(41.3)$ & $2(13.3)$ & & $18(36.7)$ & $10(34.5)$ & \\
\hline \multicolumn{7}{|c|}{ Potassium } \\
\hline Absent & $11(17.5)$ & $3(20.0)$ & 0.532 & $8(16.3)$ & $6(20.7)$ & 0.627 \\
\hline Present & $52(82.5)$ & $12(80.0)$ & & 41 (83.7) & $23(79.3)$ & \\
\hline \multicolumn{7}{|c|}{\begin{tabular}{|l|} 
Calcium \\
\end{tabular}} \\
\hline Absent & $1(1.6)$ & $0(0.0)$ & 0.807 & $1(2.0)$ & $0(0.0)$ & 0.628 \\
\hline Present & $62(98.4)$ & $15(100.0)$ & & 48 (98.0) & $29(100.0)$ & \\
\hline \multicolumn{7}{|c|}{ Chromium } \\
\hline Absent & $40(63.5)$ & $5(33.3)$ & 0.034 & $39(59.2)$ & $16(55.2)$ & $\begin{array}{l}0.729 \\
\end{array}$ \\
\hline Present & $23(36.5)$ & $10(66.7)$ & & $20(40.8)$ & 13 (44.8) & \\
\hline \multicolumn{7}{|c|}{\begin{tabular}{|l} 
Manganese \\
\end{tabular}} \\
\hline Absent & $45(71.4)$ & $7(46.7)$ & 0.067 & 35 (71.4) & 17 (58.6) & 0.246 \\
\hline Present & $18(28.6)$ & $8(53.3)$ & & $14(28.6)$ & $12(41.4)$ & \\
\hline \multicolumn{7}{|l|}{ Iron } \\
\hline Absent & $0(0.0)$ & $0(0.0)$ & 1.000 & $0(0.0)$ & $0(0.0)$ & 1.000 \\
\hline Present & $63(100.0)$ & $15(100.0)$ & & $49(100.0)$ & $29(100.0)$ & \\
\hline \multicolumn{7}{|l|}{ Cobalt } \\
\hline Absent & $54(85.7)$ & $15(100.0)$ & 0.129 & 43 (87.8) & $26(89.7)$ & 0.554 \\
\hline Present & $9(14.3)$ & $0(0.0)$ & & $6(12.2)$ & $3(10.3)$ & \\
\hline \multicolumn{7}{|l|}{ Nickel } \\
\hline Absent & $54(85.7)$ & $13(86.7)$ & 0.645 & 41 (83.7) & 26 (89.7) & 0.353 \\
\hline Present & $9(14.3)$ & $2(13.3)$ & & $8(16.3)$ & $3(10.3)$ & \\
\hline \multicolumn{7}{|l|}{ Copper } \\
\hline Absent & $3(4.8)$ & $1(6.7)$ & 0.561 & $4(8.2)$ & $0(0.0)$ & 0.149 \\
\hline Present & $60(95.2)$ & 14 (93.3) & & 44 (91.8) & $29(100.0)$ & \\
\hline \multicolumn{7}{|l|}{ Zinc } \\
\hline Absent & $0(0.0)$ & $0(0.0)$ & 1.000 & $0(0.0)$ & $0(0.0)$ & 1.000 \\
\hline Present & $63(100.0)$ & $15(100.0)$ & & $49(100.0)$ & $29(100.0)$ & \\
\hline \multicolumn{7}{|l|}{ Arsenic } \\
\hline Absent & $18(28.6)$ & $7(46.7)$ & 0.177 & $16(32.7)$ & $9(31.0)$ & 0.544 \\
\hline Present & $45(71.4)$ & $8(53.3)$ & & $33(67.3)$ & $20(69.0)$ & \\
\hline \multicolumn{7}{|c|}{ Bromine } \\
\hline Absent & $18(28.6)$ & $7(46.7)$ & 0.177 & $16(32.7)$ & $9(31.0)$ & 0.544 \\
\hline Present & 45 (71.4) & $8(53.3)$ & & 33 (67.3) & $20(69.0)$ & \\
\hline
\end{tabular}

Table 2. Elemental characterization in association recurrence and death. Data represented as absolute counts (\%).

ERK1/2 and was associated with decreased survival. Britschgi et al. ${ }^{49}$ demonstrated that calcium-activated chloride channels (ANO1) promoted cancer progression in tumors, such as breast cancer.

In this study, the presence of chlorine as a protective factor for recurrence and better disease-free survival can be explained by several factors: 1) alteration in intracellular $\mathrm{pH}$ - tumor cells reside in an acidic environment and intracellular processes compensate for conditions to maintain viability and proliferation; ${ }^{50} 2$ ) changes in the actin cytoskeleton - several members of the chloride channel (CLC) family bind to actin and this binding is important for regulation of $\mathrm{Cl}^{-}$transport by these proteins; ${ }^{51} 3$ ) cell cycle interference-chloride channel activity of the CLC and CLIC (Chloride intracellular channel) families were associated with changes in cell cycle, and CLC2 is regulated by $\mathrm{cdc} 2 /$ cyclinB, suggesting a mechanism for $\mathrm{M}$ phase activation; ${ }^{52} \mathrm{CLIC}-4$ is located in the centrosome and middle of the M-phase cells and CLIC-1 is expressed on the plasma membrane during M phase in CHO-K1 cells ${ }^{53}$. 


\begin{tabular}{|c|c|c|c|c|c|c|c|c|}
\hline & \multicolumn{4}{|c|}{ Logistic regression model } & \multicolumn{4}{|l|}{ Cox model } \\
\hline & \multicolumn{2}{|l|}{ Recurrence } & \multicolumn{2}{|l|}{ Death } & \multicolumn{2}{|c|}{ Recurrence-free survival } & \multicolumn{2}{|l|}{ Overall survival } \\
\hline & OR (CI 95\%) & P- & OR (CI 95\%) & P- & HR (CI 95\%) & P- & HR (CI 95\%) & P- \\
\hline \multicolumn{9}{|l|}{$\mathbf{N}\left(\mathrm{TNM}^{1}\right)^{1}$} \\
\hline Negative & 1 & & 1 & & 1 & & 1 & \\
\hline Positive & $4.912(1.20-20.06)$ & 0.027 & $5.614(1.93-16.26)$ & 0.001 & $3.081(1.38-6.85)$ & 0.006 & $3.081(1.38-6.85)$ & 0.006 \\
\hline \multicolumn{9}{|l|}{ Sex } \\
\hline Female & 1 & & & & & & & \\
\hline Male & $9.095(0.95-87.10)$ & 0.055 & & & & & & \\
\hline \multicolumn{9}{|l|}{ Age } \\
\hline$\leq 63$ years & 1 & & & & 1 & & & \\
\hline$>63$ years & $0.194(0.04-0.93)$ & 0.040 & & & $0.264(0.07-0.95)$ & 0.042 & & \\
\hline \multicolumn{9}{|l|}{ CAC } \\
\hline $\mathrm{No}^{2}$ & & & 1 & & & & 1 & \\
\hline Yes $^{3}$ & & & $2.844(1.00-8.01)$ & 0.048 & & & $1.804(0.80-4.06)$ & 0.154 \\
\hline \multicolumn{9}{|l|}{ Chlorine } \\
\hline Absence & 1 & & & & 1 & & & \\
\hline Present & $0.105(0.01-0.63)$ & 0.014 & & & $0.194(0.04-0.87)$ & 0.033 & & \\
\hline \multicolumn{9}{|l|}{ Manganese } \\
\hline Absence & & & & & & & 1 & \\
\hline Present & & & & & & & $1.751(0.81-3.75)$ & 0.151 \\
\hline
\end{tabular}

Table 3. Multivariable logistic regression model and Cox model of prognostic factors and survival in patients which oral squamous cell carcinoma. OR, Odds Ratio; HR, Hazard Ratio; CAC, Current alcohol consumption; CI, confidence interval; ${ }^{1}$ TNM classification 7 th edition; ${ }^{2}$ No, Never/Former; ${ }^{3}$ Yes, Current.

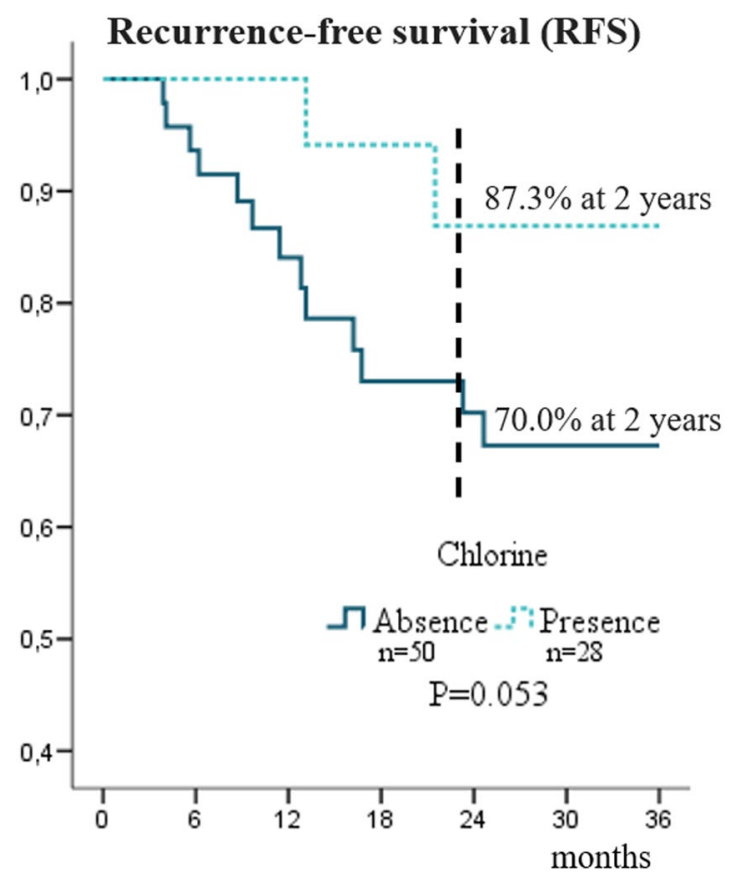

Figure 2. Recurrence-free survival (RFS) curves of patients with squamous cell carcinoma of the oral cavity according to status of chlorine.

In conclusion, this study, for the first time, demonstrates the presence of important trace elements and non-essential or toxic elements in samples of OCSCC. Tobacco use predisposes patients to the accumulation of potentially toxic and/or carcinogenic elements. Both manganese and chlorine elements proved to be important prognostic and survival factors for patients with head and neck cancer. Furthermore, as there is no consensus on which elements, beyond the physiological ones, that could be found in head and neck cancer, the present study can serve as a basis for new quantitative studies, where efforts would be directed towards the analysis of the levels of such elements, which would save time and resources for researchers, since these analyzes are costly. 


\begin{tabular}{|c|c|c|c|c|c|c|c|}
\hline \multirow[b]{2}{*}{ Characteristic } & \multirow[b]{2}{*}{$\begin{array}{l}\text { All patients } \\
(\mathrm{n}=78)\end{array}$} & \multicolumn{3}{|c|}{ Recurrence } & \multicolumn{3}{|l|}{ Death } \\
\hline & & \begin{tabular}{|l|} 
No \\
$(n=63)$
\end{tabular} & \begin{tabular}{|l|} 
Yes \\
$(\mathrm{n}=15)$
\end{tabular} & P- & $\begin{array}{l}\text { No } \\
(n=49)\end{array}$ & $\begin{array}{l}\text { Yes } \\
(\mathrm{n}=29)\end{array}$ & P- \\
\hline Age & $63.7( \pm 11.0)^{*}$ & & & & & & \\
\hline$\leq 63$ years & $41(52.6)$ & $29(46.0)$ & $12(80.0)$ & 0.017 & $22(44.9)$ & $19(65.5)$ & 0.078 \\
\hline$>63$ years & $37(47.4)$ & $34(54.0)$ & $3(20.0)$ & & $27(55.1)$ & $10(34.5)$ & \\
\hline \multicolumn{8}{|l|}{ Sex } \\
\hline Female & $24(30.7)$ & $23(36.5)$ & $1(6.7)$ & 0.020 & $19(38.8)$ & $5(17.2)$ & 0.039 \\
\hline Male & $54(69.7)$ & $40(63.5)$ & $14(93.3)$ & & $30(61.2)$ & $24(82.8)$ & \\
\hline \multicolumn{8}{|l|}{ Smoking status } \\
\hline Never & $14(17.9)$ & $14(22.2)$ & $0(0.0)$ & 0.121 & $12(24.5)$ & $2(6.9)$ & 0.051 \\
\hline Former & $23(29.5)$ & $17(27.0)$ & $6(40.0)$ & & $16(32.7)$ & $7(24.1)$ & \\
\hline Current & $41(52.6)$ & $32(50.8)$ & $9(60.0)$ & & $21(42.9)$ & $20(69.0)$ & \\
\hline \multicolumn{8}{|c|}{$\begin{array}{l}\text { History of tobacco } \\
\text { consumption }\end{array}$} \\
\hline $\mathrm{No}^{1}$ & $14(17.9)$ & $14(22.2)$ & $0(0.0)$ & 0.037 & $12(24.5)$ & $2(6.9)$ & 0.045 \\
\hline Yes $^{2}$ & $64(82.1)$ & $49(77.8)$ & $15(100.0)$ & & $37(75.5)$ & $27(93.1)$ & \\
\hline \multicolumn{8}{|c|}{ Current tobacco consumption } \\
\hline $\mathrm{No}^{3}$ & 37 (47.4) & $31(49.2)$ & $6(40.0)$ & 0.521 & $28(57.1)$ & $9(31.0)$ & 0.022 \\
\hline Yes $^{4}$ & $41(52.6)$ & $32(50.2)$ & $9(60.0)$ & & $21(42.9)$ & $20(69.0)$ & \\
\hline \multicolumn{8}{|l|}{ Alcohol use } \\
\hline Never & $17(21.8)$ & $17(27.0)$ & $0(0.0)$ & 0.042 & $13(26.5)$ & $4(13.4)$ & 0.040 \\
\hline Former & $27(34.6)$ & $22(34.9)$ & $5(33.3)$ & & $20(40.8)$ & $7(24.1)$ & \\
\hline Current & $34(43.6)$ & $24(38.1)$ & $10(66.7)$ & & $16(32.7)$ & $18(62.1)$ & \\
\hline \multicolumn{8}{|c|}{$\begin{array}{l}\text { History of alcohol } \\
\text { consumption }\end{array}$} \\
\hline $\mathrm{No}^{1}$ & $17(21.8)$ & $17(27.0)$ & $0(0.0)$ & 0.016 & $13(26.5)$ & $4(13.8)$ & 0.151 \\
\hline Yes $^{2}$ & $61(78.2)$ & $46(73.0)$ & $15(100.0)$ & & $36(73.5)$ & $25(86.2)$ & \\
\hline \multicolumn{8}{|c|}{ Current alcohol consumption } \\
\hline $\mathrm{No}^{3}$ & $44(56.4)$ & $39(61.9)$ & $5(33.3)$ & 0.043 & $33(67.3)$ & $11(37.9)$ & 0.011 \\
\hline Yes $^{4}$ & $34(43.6)$ & $24(38.1)$ & $10(66.7)$ & & $16(32.7)$ & $18(62.1)$ & \\
\hline
\end{tabular}

Table 4. Characteristics of patients which oral squamous cell carcinoma. ${ }^{1}$ No; Never; ${ }^{2}$ Yes, Former/Current; ${ }^{3}$ No, Never/Former; ${ }^{4}$ Yes, Current; Data represented as absolute counts (\%); ${ }^{*}$ Age, Mean (SD).

\section{Materials and Methods}

Samples. Samples were collected by the Head and Neck Genome Project (GENCAPO). For this study, we obtained 78 samples of tumor tissues from 78 patients diagnosed with OCSCC. In order to avoid possible of the samples with paraffin, xylene and alcohol, the quality and integrity of these reagents were checked for purity in each batch used. Diagnosis of OCSCC was confirmed by two pathologists and the patients were treated surgically at the Department of Head and Neck Surgery at the Cancer Institute Arnaldo Vieira de Carvalho (ICAVC), São Paulo, Brazil, from January 2012 to May 2015. The follow-up was at least 24 months after surgery. Exclusion criteria were as follows: previous surgical or chemotherapeutic treatments, distant metastasis, absence of removal of cervical lymph nodes, and positive surgical margins.

The patients exhibited epidemiological profiles and classic prognoses of patients with OCSCC, such as: mean age of $63.7 \pm 11.0 \mathrm{yr}$, including 54 men $(69.3 \%)$ and 24 women $(30.7 \%)$, with male sex - being a risk factor for recurrence $(\mathrm{OR}=9,095, \mathrm{CI}=0.95-87.10$, Table 3$)$. The smoking status was 14 non-smokers $(17.9 \%), 23$ former smokers (29.5\%), and 41 current smokers (52.6\%). Alcohol use was 17 non-drinkers (21.8\%), 27 former drinkers (34.6\%), and 34 current drinkers (43.6\%), with current alcohol consumption being identified as a risk factor for death by cancer $(\mathrm{OR}=2.844, \mathrm{CI}=1.00-8.01$; Table 3$)$, as well as a risk factor for worse overall survival $(\mathrm{HR}=1.804, \mathrm{CI}=0.80-4.06)$. Epidemiological and prognostic characteristics are summarized in Table 4.

Tissue microarrays. Tissue microarrays (TMA) were made using $10 \%$ buffered formalin-fixed sections embedded in paraffin of 78 primary oral cavity epidermoid carcinomas from patients surgically treated at the ICAVC, following the methodology described by Cajaiba et al. ${ }^{54}$. Two representative tumor areas were examined by two experienced pathologists from slides stained with hematoxylin and eosin. Two 1.5-mm diameter cylinders were drilled into each sample and reintroduced into paraffin receptor blocks using a tissue microarrayer (BEECHER INSTRUMENTS, Silver Spring, MD, USA). Sections were then removed from the TMA and mounted on microscopy slides. A pathologist checked the content of each spot. Spots bent or missing more than $70 \%$ of the tissue were excluded.

Qualitative elemental characterization. For the qualitative elemental characterization, tumor tissue samples (mean thickness of $450 \mu \mathrm{m}$; mean density of $0.54 \mathrm{~g} / \mathrm{cm}^{3}$ ) were removed from the TMA and subjected to dewaxing and rehydration processes with xylene, alcohol (the quality and integrity of these reagents were checked 
for purity in each batch used) and ultrapure water. They were then deposited in plastic support with Ultralene film (SPEX SAMPLEPREP, Metuchen, NJ, USA) and sent to the D09-XRF beamline equipment at the Brazilian Synchrotron Light Laboratory, Campinas, São Paulo, Brazil ${ }^{55}$, for analysis by micro X-Ray Fluorescence ( $\mu$-XRF). To obtain the spectra, a white beam with a power range of 4 to $24 \mathrm{keV}$ and dimensions of $2 \mathrm{~mm}^{2}$ was used to excite the samples for 20 seconds. The fluorescent $\mathrm{X}$ rays emitted by the samples were detected using a high-resolution spectrometer, based on a Silicon Drift detector with an $8-\mu \mathrm{m}$ thick beryllium window and an active area of $7 \mathrm{~mm}^{2}$. A $45-\mathrm{mm}$ aluminum filter was used in the bundle and the sample holder, positioned at $21 \mathrm{~mm}$ and at a $45^{\circ}$ angle to the detector. All measurements were performed at a temperature of $23 \pm 2{ }^{\circ} \mathrm{C}$ and a pressure of 1 ATM.

Nine measurements were performed in a $3 \times 3$ matrix and were averaged to obtain the final spectrum used in the analyses. For the adjustment of the characteristic X-ray spectra, determination of the elements and their respective fluorescent intensities, a certified reference sample, Standard Reference Material 1577b "Bovine Liver" (NATIONAL INSTITUTE OF STANDARDS AND TECHNOLOGY, Gaithersburg, MD, USA), was subjected to the same experimental parameters described above. Analysis of the spectrum and determination of the characteristic peaks of each element was carried out using PYMCA 5.0.0 ${ }^{56}$. Each spectrum was verified, the characteristic peaks of the elements identified, and then identification values were assigned as (0) for absence and (1) for the presence of the characteristic peak.

Statistical analysis. Samples were categorized according to patients' smoking habits: nonsmokers (never), past smokers (former) and current smokers (current). They were categorized by the history of tobacco consumption (No: never; Yes: former/current) and by current tobacco consumption (No: never/former; Yes: current). The chi square and Fisher exact tests were used for association analysis ( $\mathrm{p}<0.05$ considered significant). Multivariable logistic regression was used to obtain OR and CI (CI $\geq 95 \%)$. Overall survival was calculated as the number of months between surgery and death for each patient or the last appointment for surviving patients. To calculate recurrence-free survival, the endpoint was the date of disease recurrence. The Kaplan-Meier model was used for survival analysis, using the Wilcoxon $\mathrm{p}$-value and the Cox proportional hazards to adjust $\mathrm{p}$-values, and to $\mathrm{HR}$ and $\mathrm{CI}(\mathrm{CI} \geq 95 \%)$. The values of OR and HR were adjusted for lymph node status (TNM). All analyses were performed using SPSS version 20 (IBM Corp., Armonk, NY, USA).

Ethics declarations. The GENCAPO project was approved by National Research Ethics Commission (CONEP) [Technical advice: 128/2012; CONEP: 16491]. This study was approved by the Committees of Ethics Research of the Federal University of Espírito Santo [CAAE: 49091515.9.0000.5060] and the Arnaldo Vieira de Carvalho Cancer Institute [CAAE: 49091515.9.3002.5471]. The study was carried out in accordance with all relevant guidelines. As this was a retrospective study, the requirement for informed consent was waived.

Received: 28 January 2020; Accepted: 3 June 2020;

Published online: 25 June 2020

\section{References}

1. Leemans, C. R., Braakhuis, B. J. M. \& Brakenhoff, R. H. The molecular biology of head and neck cancer. Nat. Rev. Cancer 11, 9-22, https://doi.org/10.1038/nrc2982 (2011).

2. Pfister, D. G. et al. Head and neck cancers, Version 2.2014. Clinical practice guidelines in oncology. J. Natl. Compr. Canc. Netw. 12, 1454-1487, https://doi.org/10.6004/jnccn.2014.0142 (2014).

3. Gillison, M. L. Current topics in the epidemiology of oral cavity and oropharyngeal cancers. Head Neck 29, 779-792, https://doi. org/10.1002/hed.20573 (2007).

4. Sapkota, A. et al. Dietary risk factors for squamous cell carcinoma of the upper aerodigestive tract in central and eastern Europe. Cancer Causes Control 19, 1161-1170, https://doi.org/10.1007/s10552-008-9183-0 (2008).

5. Han, S. et al. Epidemiology and cost analysis for patients with oral cancer in a university hospital in China. BMC Public Health 10, 1-12, https://doi.org/10.1186/1471-2458-10-196 (2010).

6. Singh, S., Pillai, S. \& Chellappan, S. Nicotinic acetylcholine receptor signaling in tumor growth and metastasis. J. Oncol. 2011, https://doi.org/10.1155/2011/456743 (2011)

7. Talhout, R. et al. Hazardous compounds in tobacco smoke. Int. J. Environ. Res. Public Health 8, 613-628, https://doi.org/10.3390/ ijerph8020613 (2011)

8. Hecht, S. S. Tobacco carcinogens, their biomarkers and tobacco-induced cancer. Nat. Rev. Cancer 3, 733-744, https://doi. org/10.1038/nrc1190 (2003).

9. Stedman, R. L. The chemical composition of tobacco and tobacco smoke. Chem. Rev. 68, 153-207, https://doi.org/10.1021/ cr60252a002 (1968).

10. Fowles, J. \& Bates, M. The Chemical Constituents in Cigarettes and Cigarette Smoke. (2000).

11. Prasad, A. S. et al. Trace elements in head and neck cancer patients: Zinc status and immunologic functions. Otolaryngol. - Head Neck Surg. 116, 624-629, https://doi.org/10.1016/S0194-59989770238-9 (1997).

12. Doerr, T. D., Marks, S. C., Shamsa, F. H., Mathog, R. H. \& Prasad, A. S. Effects of zinc and nutritional status on clinical outcomes in head and neck cancer. Nutrition 14, 489-495, https://doi.org/10.1016/s0899-9007(98)00036-7 (1998).

13. Akinmoladun, V. I., Owotade, F. J. \& Olusanya, A. A. Trace metals and total antioxidant potential in head and neck cancer patients. Ann. Afr. Med. 12, 131-134, https://doi.org/10.4103/1596-3519.112411 (2013).

14. Tiwari, R. et al. Assessment of serum copper, iron and immune complexes in potentially malignant disorders and oral cancer. Braz. Oral Res. 30, e101, https://doi.org/10.1590/1807-3107BOR-2016.vol30.0101 (2016).

15. Qayyum, M. A. \& Shah, M. H. Study of trace metal imbalances in the blood, scalp hair and nails of oral cancer patients from Pakistan. Sci. Total Environ. 593-594, 191-201, https://doi.org/10.1016/j.scitotenv.2017.03.169 (2017).

16. Elango, S., Samuel, S., Khashim, Z. \& Subbiah, U. Selenium Influences trace elements homeostasis, cancer biomarkers in squamous cell carcinoma patients administered with cancerocidal radiotherapy. Asian Pacific J. Cancer Prev. 19, 1785-1792, https://doi. org/10.22034/APJCP.2018.19.7.1785 (2018).

17. Petrosino, V. et al. The role of heavy metals and polychlorinated biphenyls (PCBs) in the oncogenesis of head and neck tumors and thyroid diseases: a pilot study. BioMetals 31, 285-295, https://doi.org/10.1007/s10534-018-0091-9 (2018).

18. Bandeira, C. M. et al. Tobacco influence in heavy metals levels in head and neck cancer cases. Environ. Sci. Pollut. Res. 25, 27650-27656, https://doi.org/10.1007/s11356-018-2668-9 (2018). 
19. Chen, F. et al. Serum copper and zinc levels and the risk of oral cancer: A new insight based on large-scale case-control study. Oral Dis. 25, 80-86, https://doi.org/10.1111/odi.12957 (2019).

20. Wadhwa, S. K., Kazi, T. G., Afridi, H. I. \& Talpur, F. N. Interaction between carcinogenic and anti-carcinogenic trace elements in the scalp hair samples of different types of Pakistani female cancer patients. Clin. Chim. Acta 439, 178-184, https://doi.org/10.1016/j. cca.2014.10.007 (2015).

21. Wozniak, A. et al. Metal concentrations in hair of patients with various head and neck cancers as a diagnostic aid. BioMetals 29, 81-93, https://doi.org/10.1007/s10534-015-9899-8 (2016).

22. Dziewulska, A., Janiszewska-Olszowska, J., Bachanek, T. \& Grocholewicz, K. Salivary mineral composition in patients with oral cancer. Magnes. Res. 26, 120-124, https://doi.org/10.1684/mrh.2013.0346 (2013).

23. Shetty, S. R. et al. Status of trace elements in saliva of oral precancer and oral cancer patients. J. Cancer Res. Ther. 11, 146-149, https:// doi.org/10.4103/0973-1482.137973 (2015).

24. Zaichick, V. Y., Tsyb, A. F. \& Vtyurin, B. M. Trace elements and thyroid cancer. Analyst 120, 817-821, https://doi.org/10.1039/ an9952000817 (1995).

25. Baltaci, A. K., Dundar, T. K., Aksoy, F. \& Mogulkoc, R. Changes in the Serum Levels of Trace Elements Before and After the Operation in Thyroid Cancer Patients. Biol. Trace Elem. Res. 175, 57-64, https://doi.org/10.1007/s12011-016-0768-2 (2017).

26. Majewska, U. et al. An elemental correlation study in cancerous breast tissue by total reflection x-ray fluorescence. Biol. Trace Elem. Res. 60, 91-100, https://doi.org/10.1007/BF02783312 (1997).

27. Geraki, K., Farquharson, M. J. \& Bradley, D. A. X-ray fluorescence and energy dispersive x-ray diffraction for the quantification of elemental concentrations in breast tissue. Phys. Med. Biol. 49, 99-110, https://doi.org/10.1088/0031-9155/49/1/007 (2004).

28. Silva, M. P., Soave, D. F., Ribeiro-Silva, A. \& Poletti, M. E. Trace elements as tumor biomarkers and prognostic factors in breast cancer: A study through energy dispersive x-ray fluorescence. BMC Res. Notes 5, 1-11, https://doi.org/10.1186/1756-0500-5-194 (2012).

29. Hoffmann, D. \& Hoffmann, I. Letters to the Editor - Tobacco smoke components. Beiträge zur Tab. Int. to Tob. Res. 18, 49-52, https:// doi.org/10.2478/cttr-2013-0668 (1998).

30. Arain, S. S. et al. Estimation of Nickel in Different Smokeless Tobacco Products and Their Impact on Human Health of Oral Cancer Patients. Nutr. Cancer 67, 1063-1074, https://doi.org/10.1080/01635581.2015.1073758 (2015).

31. Arain, S. S. et al. Correlation of Arsenic Levels in Smokeless Tobacco Products and Biological Samples of Oral Cancer Patients and Control Consumers. Biol. Trace Elem. Res. 168, 287-295, https://doi.org/10.1007/s12011-015-0355-y (2015).

32. Rogers, M. A. M., Thomas, D. B., Vaughan, T. L. \& Nevissi, A. E. A Case-Control Study of Element Levels and Cancer of the Upper Aerodigestive Tract. Cancer Epidemiol. Biomarkers Prev. 2, 305-312 (1993).

33. Unkiewicz-Winiarczyk, A., Bagniuk, A., Gromysz-Kałkowska, K. \& Szubartowska, E. Calcium, magnesium, iron, zinc and copper concentration in the hair of tobacco smokers. Biol. Trace Elem. Res. 128, 152-160, https://doi.org/10.1007/s12011-008-8266-9 (2009).

34. Khlifi, R. et al. Blood nickel and chromium levels in association with smoking and occupational exposure among head and neck cancer patients in Tunisia. Environ. Sci. Pollut. Res. 20, 8282-8294, https://doi.org/10.1007/s11356-013-1466-7 (2013).

35. Yuan, T. H. et al. Possible association between nickel and chromium and oral cancer: A case-control study in central Taiwan. Sci. Total Environ. 409, 1046-1052, https://doi.org/10.1016/j.scitotenv.2010.11.038 (2011).

36. Tsai, K. Y., Su, C. C., Chiang, C. T., Tseng, Y. T. \& Lian, I. B. Environmental heavy metal as a potential risk factor for the progression of oral potentially malignant disorders in central Taiwan. Cancer Epidemiol. 47, 118-124, https://doi.org/10.1016/j. canep.2017.02.003 (2017).

37. Achmad, R. T., Budiawan \& Auerkari, E. I. Effects of chromium on human body. Annu. Res. Rev. Biol. 13, 1-8 (2017).

38. Imhoff, L. C. R. et al. Prognostic value of continued smoking on survival and recurrence rates in patients with head and neck cancer: A systematic review. Head Neck 38, E2214-E2220, https://doi.org/10.1002/hed.24082 (2016).

39. Farshadpour, F. et al. Survival analysis of head and neck squamous cell carcinoma: influence of smoking and drinking. Head Neck 33, 817-823, https://doi.org/10.1002/hed.21549 (2011)

40. Rodrigues, J. L., Batista, B. L., Nunes, J. A., Passos, C. J. S. \& Barbosa, F. Evaluation of the use of human hair for biomonitoring the deficiency of essential and exposure to toxic elements. Sci. Total Environ. 405, 370-376, https://doi.org/10.1016/j. scitotenv.2008.06.002 (2008).

41. Foskett, J. K. ClC and CFTR chloride channel gating. Annu. Rev. Physiol. 60, 689-717, https://doi.org/10.1146/annurev. physiol.60.1.689 (1998).

42. Pechova, A. \& Pavlata, L. Chromium as an essential nutrient: A review. Vet. Med. (Praha). 52, 1-18 (2007).

43. Prevarskaya, N., Skryma, R. \& Shuba, Y. Ion channels and the hallmarks of cancer. Trends Mol. Med. 16, 107-121, https://doi. org/10.1016/j.molmed.2010.01.005 (2010)

44. Cuddapah, V. A. \& Sontheimer, H. Molecular interaction and functional regulation of ClC-3 by Ca $2+/$ calmodulin-dependent protein kinase II (CaMKII) in human malignant glioma. J. Biol. Chem. 285, 11188-11196, https://doi.org/10.1074/jbc.M109.097675 (2010).

45. Chen, F., Ding, M., Castranova, V. \& Shi, X. Carcinogenic metals and NF-кB activation. Mol. Cell. Biochem. 222, 159-171 (2001).

46. Suh, K. \& Yuspa, S. Intracellular Chloride Channels: Critical Mediators of Cell Viability and Potential Targets for Cancer Therapy. Curr. Pharm. Des. 11, 2753-2764, https://doi.org/10.2174/1381612054546806 (2005).

47. Ruiz, C. et al. Enhanced expression of ANO1 in head and neck squamous cell carcinoma causes cell migration and correlates with poor prognosis. PLoS One 7, e43265, https://doi.org/10.1371/journal.pone.0043265 (2012).

48. Duvvuri, U. et al. TMEM16A induces MAPK and contributes directly to tumorigenesis and cancer progression. Cancer Res. 72 , 3270-3281, https://doi.org/10.1158/0008-5472.CAN-12-0475-T (2012).

49. Britschgi, A. et al. Calcium-activated chloride channel ANO1 promotes breast cancer progression by activating EGFR and CAMK signaling. Proc. Natl. Acad. Sci. USA 110, https://doi.org/10.1073/pnas.1217072110 (2013).

50. Webb, S. D., Sherratt, J. A. \& Fish, R. G. Modelling tumour acidity and invasion. Novartis Found. Symp. 240, 169-181, https://doi. org/10.1002/0470868716.ch12 (2001).

51. Hryciw, D. H. et al. Cofilin interacts with ClC-5 and regulates albumin uptake in proximal tubule cell lines. J. Biol. Chem. 278, 40169-40176, https://doi.org/10.1074/jbc.M307890200 (2003).

52. Bösl, M. R. et al. Male germ cells and photoreceptors, both dependent on close cell-cell interactions, degenerate upon ClC-2 Clchannel disruption. EMBO J. 20, 1289-1299, https://doi.org/10.1093/emboj/20.6.1289 (2001).

53. Berryman, M. A. \& Goldenring, J. R. CLIC4 Is Enriched at Cell-Cell Junctions and Colocalizes With AKAP350 at the Centrosome and Midbody of Cultured Mammalian Cells. Cell Motil. Cytoskeleton 56, 159-172, https://doi.org/10.1002/cm.10141 (2003).

54. Cajaiba, M. M. et al. Hepatoblastomas and liver development: a study of cytokeratin immunoexpression in twenty-nine hepatoblastomas. Pediatr Dev Pathol 9, 196-202, https://doi.org/10.2350/05-12-0002.1 (2006).

55. Pérez, C. A. et al. Synchrotron radiation $\mathrm{x}$-ray fluorescence at the LNLS: Beamline instrumentation and experiments. X-Ray Spectrom. 28, 320-326 10.1002/(SICI)1097-4539(199909/10)28:5<320::AID-XRS359>3.0.CO;2-1 (1999).

56. Solé, V. A., Papillon, E., Cotte, M., Walter, P. \& Susini, J. A multiplatform code for the analysis of energy-dispersive X-ray fluorescence spectra. Spectrochim. Acta - Part B At. Spectrosc. 62, 63-68, https://doi.org/10.1016/j.sab.2006.12.002 (2007). 


\section{Acknowledgements}

We would like to thank the Arnaldo Vieira de Carvalho Cancer Institute for making the OCSCC samples available through the Head and Neck Genome Project (http://www.gencapo.famerp.br/). We also thank Brazilian Synchrotron Light Laboratory for carrying out the analysis of micro X-Ray Fluorescence [Proposal 20150102 - Elemental micro-imaging and quantification of squamous cell carcinoma head and neck, microenvironment tumor and its relationship with hypoxia gene expression and oxidative stress]. We would like to thank Editage (www.editage.com) for English language editing. This work was supported mostly by Fundação de Amparo à Pesquisa e Inovação do Espírito Santo [grant numbers 69918147/15 and 80706487/18] and in part by the Fundação de Amparo à Pesquisa do Estado de São Paulo [grant numbers 04/12054-9 and 10/51168-0], by Conselho Nacional de Desenvolvimento Científico e Tecnológico [grant numbers 308331/2017-6 and 430756/2018-6] and Coordenação de Aperfeiçoamento de Pessoal de Nível Superior - Brasil (CAPES) - Finance Code 001.

\section{Author contributions}

A.B.A., A.L.E.M.d.A., L.O.T. C.J.G.P. and A.M.A.-d.-S. conceived and designed of the study. R.P.d.S., R.C., M.B.C. and E.H.T. collected clinical specimen and data. A.B.A, A.L.E.M.d.A., S.O.M. and C.J.G.P. performed the elementary characterization. A.B.A., A.L.E.M.d.A., M.M.d.O. and L.d.L.M. performed IHC. K.C.S., E.T.K., F.D.N. and B.V.N. performed a critical review of the manuscript. A.B.A., A.L.E.M.d.A., A.R.B. and M.S. performed data analysis. A.B.A. wrote the manuscript. All authors reviewed the manuscript, agreed for the author's own contributions, and approved the submitted version.

\section{Competing interests}

The authors declare no competing interests.

\section{Additional information}

Correspondence and requests for materials should be addressed to A.B.A.

Reprints and permissions information is available at www.nature.com/reprints.

Publisher's note Springer Nature remains neutral with regard to jurisdictional claims in published maps and institutional affiliations.

Open Access This article is licensed under a Creative Commons Attribution 4.0 International License, which permits use, sharing, adaptation, distribution and reproduction in any medium or format, as long as you give appropriate credit to the original author(s) and the source, provide a link to the Creative Commons license, and indicate if changes were made. The images or other third party material in this article are included in the article's Creative Commons license, unless indicated otherwise in a credit line to the material. If material is not included in the article's Creative Commons license and your intended use is not permitted by statutory regulation or exceeds the permitted use, you will need to obtain permission directly from the copyright holder. To view a copy of this license, visit http://creativecommons.org/licenses/by/4.0/.

(C) The Author(s) 2020 